\title{
Enhancing Senior High School Students' Scientific Attitude Through Problem Based Learning
}

\author{
Indah Wulandari \\ Department of Science Education \\ Universitas Syiah Kuala \\ Banda Aceh, Indonesia
}

\author{
Muhammad Syukri* \\ Department of Physics Education \\ Universitas Syiah Kuala \\ Banda Aceh, Indonesia \\ *syukri.physics@unsyiah.ac.id
}

\author{
Murniati \\ Department of Education Management \\ Universitas Syiah Kuala \\ Banda Aceh, Indonesia
}

\begin{abstract}
Problem based learning has a very important role in the world of education. Through this model students are hoped able to develop various skills including their scientific attitudes. However, many teachers still use conventional models during the teaching and learning process in the classroom. The purpose of this study was to determine how the influence of PBL on students' scientific attitudes on static fluid concept. The method used in this research is a quasi-experiment. The population in this study were students of class X SMAN 2 Banda Aceh, while the sample selection technique was purposive sampling. The sample in this study consisted of two classes, namely class XI4 totaling 36 students and class XI5 totaling 36 students. The data collection procedure used an observation sheet and a questionnaire. The data analysis technique was performed using a percentage formula. The results of the mean difference test for scientific attitudes showed. The percentage results showed that after implementing PBL-based learning, students' scientific attitudes have improved in each indicator. The are expected to be empirical evidence that the PBL model is very suitable to be implemented in schools, especially to improve students' scientific attitudes.
\end{abstract} result

Keywords—problem based learning, scientific attitude, learning

\section{INTRODUCTION}

Teaching and learning process generally carried out by teachers give more lectures and exercises do the questions quickly without understanding the concepts in depth [1]. This causes students to be less trained in their rational powers when solving problems and applying physics concepts that have been learned in real life [2]. The low learning outcomes of students in recent years have been influenced by several factors, including the lack of scientific attitudes of students and also the methods used by teachers were not appropriate in the teaching and learning process [3]. Teachers' efforts are being made to improve the teaching process by selecting the appropriate learning model. Teachers must be able to choose a suitable method to be able to make students more active by conducting experiments, so that students can improve scientific attitudes because physics is a science that studies natural phenomena [4]. Effective learning will only occur when students are actively involved in the problems presented during the learning process. One learning model that involves active students is the Problem Based Learning (PBL).

Problem based learning has a very significant role in the world of education, because the problem-based learning model has the benefit of being able to help students in developing their thinking skills, problem solving skills and high intellectual skills so that students can easily understand real situations and simulated situations and become independent and autonomous learners [5]. Learning with the PBL model can have a very significant effect on student learning outcomes and can also make students active and have high-level thinking skills, be independent and confident when delivering material [6]. The same thing also delivered by Ernawati et al that $\mathrm{p}$ roses are certainly going to show the maximum results if executed through approach to learning students are active [7].

Physics learning that is expected to take place in schools is a learning that is in accordance with the objectives of learning physics itself, namely the ongoing learning which is based on scientific principles, both scientific attitudes, scientific processes and scientific products. To bring up students' scientific attitudes, a learning model is also needed in accordance with the indicators possessed by the student's scientific attitude. A scientific person is a person who has seven kinds of scientific attitudes, namely, a curious attitude, a critical attitude, an open attitude, an objective attitude, an attitude of willingness to respect other people's work, an 
attitude of responsibility, and an attitude of reaching forward [8].

The PBL Model is one of the lessons that is supported by constructivist theory so that students can form their own knowledge, develop higher skills and inquiry, and increase self-confidence. The PBL model can provide opportunities for students to explore, collect and analyze data completely to solve the problems at hand. So those students are able to think critically, analytically, systematically and logically in finding alternative problem solving [9].

The PBL model in this study is also to determine the effect of students' scientific attitudes towards static fluid material. The PBL learning method is a student-centered learning model capable of fostering the ability to think, work, and have a scientific attitude. The problem-solving process carried out by students in learning will provide a better understanding and become more meaningful, so that if students have been involved in the learning process carried out by the teacher, it is expected that a scientific attitude will be created. It can be concluded that learning using PBL will encourage the formation of a scientific attitude in oneself [10]. The application of PBL in this study was carried out by measuring five indicators including; curious, flexible, critical, honest, and thorough.

Based on the results of preliminary observations, physics learning in schools generally emphasizes the cognitive aspects only, while affective and psychomotor are neglected. The same thing was also revealed by Pohan that what was developed in learning tended to be cognitive aspects, so that students only gained knowledge [11]. In essence, in learning these three aspects must be considered. The conditions in the field show that in learning physics in class, students tend to be passive, do not dare to express opinions and are embarrassed to ask questions, so that there is a lack of interaction between students and teachers, and students and students.

The low scientific attitude of students towards learning physics is because the teaching-learning rocess focus more on learning outcomes, so that the value of students' scientific attitudes received less attention. As a result, students are less interested in following the learning material taught by the teacher, making students feel bored and not interested in following learning material so that there is no motivation from within themselves to try to understand what is taught by the teacher which will affect their learning.

\section{RESEARCH METHODS}

This research was conducted using experimental methods. The experimental method was designed with a pretest posttest control group design. The implementation is carried out in two classes, namely the experimental class and the control class. The population in this study were students of class X SMAN 2 Banda Aceh, while the sample selection technique was in the form of purposive sampling. The sample in the study consisted of two classes, namely class XI4 totaling 36 students and class XI5 totaling 36 students. Data collection procedures used test questions and questionnaires. Data analysis techniques were performed using $t$ test and percentage formula. The research procedure was carried out at the beginning of the meeting giving pretest questions to both classes, both the experimental class and the control class. After the students completed the pretest questions, the next meeting carried out learning activities in the classroom. In the experimental class, the treatment was carried out by applying the PBL model. The control class uses direct instruction model learning.

Learning activities are carried out in accordance with the learning implementation plan, namely: preliminary, core and closing activities. Stage's latter gives about posttest in both classes are to know the finding of the final study of students and provide a questionnaire to determine the response of students how the effects of problem-based learning model of the scientific attitude.

\section{RESULTS AND DISCUSSION}

The scientific attitude is an individual's tendency to act or behave in solving a problem systematically through scientific steps [12]. The scientific attitude in this research can be measured through several indicators, including; curious, flexible, critical, honest, and thorough [13]. Students' scientific attitudes are measured through a scientific attitude questionnaire that is distributed at the end of learning activities. The influence of PBL in improving students' scientific attitude, then do different test average. More details will be showed in Table 1 .

TABLE I. THE DIFFERENCE OF AVARAGE SCORE IN PRETEST STUDENTS' SCIENTIFIC ATTITUDES IN THE EXPERIMENTAL ClASS AND THE CONTROL CLASS

\begin{tabular}{|c|c|c|c|c|}
\hline Class & $\begin{array}{c}\text { Average } \\
\text { Score }\end{array}$ & Normality* & $\underset{* *}{\text { Homogeneity }}$ & $\underset{* * *}{\text { Significance }}$ \\
\hline Experiment & 56.9 & $\begin{array}{l}X^{2}{ }_{h i t}<X^{2} \text { tab } \\
(6.28)>(12.6) \\
\text { (normally } \\
\text { distributed) }\end{array}$ & \multirow{2}{*}{$\begin{array}{l}\mathrm{F}_{\text {hit }}<\mathrm{F}_{\text {tab }} \\
(1.23)<(1.80) \\
\text { (homogeneous } \\
\text { ) }\end{array}$} & \multirow{2}{*}{$\begin{array}{l}\mathrm{t}_{\text {hit }}<\mathrm{t}_{\text {tab }} \\
(0.15)> \\
(1.67) \\
\text { (not } \\
\text { different) }\end{array}$} \\
\hline Control & 56.7 & $\begin{array}{l}X^{2}{ }_{h i t}<X_{\text {tab }}^{2} \\
(4.79) \\
(12.6) \\
\text { (normal) }\end{array}$ & & \\
\hline
\end{tabular}

Information:

$*$ ) = Chi square test (normally distributed, value $\mathrm{x}^{2}{ }_{\text {hits }}<\mathrm{x}^{2}$ tab, $=$ $0.05)$

$* *)=\mathrm{F}$ test (homogeneous, $\mathrm{F}_{\text {hit }}$ value $<\mathrm{F}_{\text {tab, }}=0.05$ )

$* * *)=\mathrm{t}$ test $\left(\right.$ significant, $\left.\mathrm{t}_{\text {hit }}<\mathrm{t}_{\mathrm{tab}}=0.05\right)$

Based on Table 1, it showed that the students' initial abilities in the two classes, namely the experimental class and the control class, were not significantly different. This showed that the two classes have the same initial ability. The next step was to find out the effect of PBL in improving students' scientific attitudes, then the average difference test can be carried out for the experimental posttest and control posttest. 
TABLE II. THE DIFFERENCE OF AVARAGE SCORE IN POSTTEST STUDENTS' SCIENTIFIC ATTITUDES IN THE EXPERIMENTAL ClASS AND THE CONTROL CLASS

\begin{tabular}{|c|c|c|c|c|}
\hline Class & $\begin{array}{l}\text { Average } \\
\text { Score }\end{array}$ & Normality* & $\begin{array}{c}\text { Homogeneity } \\
* * \\
\end{array}$ & $\begin{array}{c}\text { Significance } \\
* * *\end{array}$ \\
\hline Experiment & 86.8 & $\begin{array}{l}\mathrm{X}^{2}{ }_{\text {hit }}> \\
\mathrm{X}^{2}{ }_{\text {tab }} \\
(13,77)> \\
(12,6) \\
\text { (not } \\
\text { normally } \\
\text { distributed) }\end{array}$ & \multirow[t]{2}{*}{$\begin{array}{l}\mathrm{F}_{\text {hit }}<\mathrm{F}_{\text {tab }} \\
(1.19)<(1.80) \\
\text { (homogeneous) }\end{array}$} & \multirow[t]{2}{*}{$\begin{array}{l}\mathrm{t}_{\text {hit }}<\mathrm{t}_{\text {tab }} \\
(6.69)> \\
(1.67) \\
\text { (different) }\end{array}$} \\
\hline Control & 68.8 & $\begin{array}{l}\mathrm{X}^{2}{ }_{\text {hit }}<\mathrm{X}^{2} \text { tab } \\
(5.66) \\
<(12.6) \\
(\text { normal })\end{array}$ & & \\
\hline
\end{tabular}

Information:

$*$ ) = Chi square test (normally distributed, value $\mathrm{x}^{2}$ hits $<\mathrm{x}^{2}$ tab, $=$ $0.05)$

$* *)=\mathrm{F}$ test (homogeneous, $\mathrm{F}_{\text {hit }}$ value $<\mathrm{F}_{\text {tab, }}=0.05$ )

$* * *)=\mathrm{t}$ test $\left(\right.$ significant, $\left.\mathrm{t}_{\text {hit }}<\mathrm{t}_{\mathrm{tab}}=0.05\right)$

Based on Table 2 showed that the results of the difference of average score posttest, there is a significant difference between the experimental class and the control class. It's proven by a significant increase in learning activities through PBL, so that there was a positive influence on learning through PBL. Students' scientific attitudes can be measured on each indicator, both in the experimental class and in the control class. The results of the data analysis on the scientific attitude of indicators after applying the learning treatment can be seen as follows:

\section{A. Results of Scientific Attitude Analysis}

Analysis of students' scientific attitudes in the experimental and control classes was carried out by distributing a questionnaire consisting of five indicators. The five indicators will be measured how much the student's scientific attitude after learning through the PBL model and the conventional model with the highest average score, namely 4 . The results of data analysis can be seen in Table 3.

TABLE III. THE RESUlT OF ANALYSIS OF STUDENTS' SCIENTIFIC ATTITUDE INDICATORS IN THE EXPERIMENTAL AND CONTROL CLASS

\begin{tabular}{|l|l|l|l|}
\hline \multirow{2}{*}{ No. } & \multirow{2}{*}{ Indicator } & \multicolumn{2}{|c|}{ Mean } \\
\cline { 3 - 4 } & & Experiment & Control \\
\hline 1 & Curiosity & 3.57 & 2.84 \\
\hline 2 & Flexible & 3.54 & 2.90 \\
\hline 3 & Critical & 3.17 & 2.55 \\
\hline 4 & Honest & 3.33 & 2.76 \\
\hline 5 & Accuracy & 3.76 & 2.53 \\
\hline
\end{tabular}

Based on table 3, it can be seen from the average value, it showed that PBL can improve students' scientific attitudes to be better seen. The percentage results obtained are that in the experimental class each indicator increased. Meanwhile, the scientific attitude of the control class was still in the low category. The results of the percentage of students' scientific attitudes were analyzed using a Likert scale consisting of the criteria for strongly agree, agree, disagree, and strongly disagree. The results of the percentage of scientific attitudes in the two classes were added up only to students who answered agreed and strongly agreed. The results in the experimental class with PBL-based learning activities have the highest percentage of the accuracy indicator of $98.6 \%$, but the lowest percentage is the critical indicator of $86.1 \%$. The results obtained in the experimental class were much higher than those obtained in the control class. The percentage result in the highest control class is found in the flexibility indicator of $74.3 \%$, but the lowest percentage is found in the accuracy indicator $40.3 \%$.

From all indicators, it can be seen that the measurement of the scientific attitude of the experimental class was more improved than the scientific attitude in the control class. In addition, the results of the analysis proved that in the experimental class the highest indicator is the accuracy indicator. This is in accordance with the research conducted by Muhamad said that PBL can increase accuracy because students are able to use mathematical symbols appropriately, there are no errors in solving problems, observing questions related to questions correctly and re-checking the answers to the questions being worked on [14]. The low level of critical indicators was because there were still students who have not thought critically in solving problems including; learners were not focus, would have no reason to infer, do not see the clarity and overall inspection [15].

Based on the average value of the above, showed that through PBL based learning, it can increase the scientific attitude of students during activities learning static fluid material particularly well. This can also be proven from the results of research conducted by Handayani that the PBL learning model provides a different effect on students' scientific attitudes without having to be specifically addressed [16]. in every meeting, the students were training a scientific attitude so that if it is carried out continuously, the values of science will be internalized and can influence student attitudes to be more in accordance with scientific attitudes. The problem-solving process contained in the PBL model requires a confident attitude to determine the steps in solving problems that are part of a scientific attitude [17]. Basic science competencies will be fully mastered if students also have scientific performance abilities based on scientific attitudes such as making careful observations, measuring, organizing and analyzing data, organizing their own thoughts and knowing when and how to apply their knowledge to solve problems.

Furthermore, research conducted by Yoesoef said that PBL was a learning model designed so that students gain significant knowledge, which made them proficient in problem solving, has their own learning model, has the ability to participate in teams [18]. This proves that PBL learning has an influence on students' scientific attitudes. 


\section{CONCLUSION}

Model PBL gave effect to the scientific attitudes. This was obtained from the results of the average difference test showing $t_{\text {hit }}<t_{\text {tab }}$ or 6.69>1.67. The results of the percentage of indicators also prove that the indicators of curiosity increased by $95.4 \%$, flexibility by $95.8 \%$, critical by $86.1 \%$, honesty by $89.6 \%$, and accuracy by $98.6 \%$. It can be concluded that the PBL model has a significant effect on students' scientific attitudes

\section{ACKNOWLEDGMENT}

I would like to thanks to staff of SMA Negeri 2 Banda Aceh for providing a place and time to collecting data research and also thanks to the Syiah Kuala University helped make this research done well.

\section{REFERENCES}

[1] A. Orrahmah, S. An'nur and A. Salam, Meningkatkan Hasil Belajar Melalui Model Pengajaran Langsung Dengan Metode Problem Solving Pada Pembelajaran Fisika Di Kelas XII IPA 1 SMAN 10 Banjarmasin, Berkala Ilmiah Pendidikan Fisika, vol. 4, no. 2, pp.127-136. 2016.

[2] N. Nasution, Berbagai Pendekatan dan Proses Belajar dan Mengajar, Jakarta: Bumi Aksara, 2006.

[3] I. Israfiddin, A. Gani and Saminan, Penerapan Model Problem Based Learning Untuk Me ningkatkan Sikap Ilmiah Dan Hasil Belajar Peserta Didik Pada Materi Gerak Di SMP, Jurnal Pendidikan Sains Indonesia. Vol. 4, no. 01, pp. 43-51. 2016.

[4] K. Sari, M. Syukri, and A. Halim, Pengaruh Penerapan Metode Eksperimen Dan Inkuiri Terbimbing Terhadap Keterampilan Proses Sains Dan Sikap Ilmiah Siswa. Jurnal Pendidikan Sains Indonesia, vol. 3, no. 2, pp. 51-55, 2015.

[5] M. Palennari, Problem Based Learning (PBL) Memberdayakan Keterampilan Berpikir Kritis Pebelajar Pada Pembelajaran Biologi, In Seminar Nasional Biologi. 2018.

[6] M. Ibrahim, Pengajaran Berdasarkan Masalah, Surabaya: University Press, 2005

[7] Ernawati, A. Halim, and M. Syukri, Integration of Problem Based Learning (PBL) and Engineering is Elementary (EiE) to improve students' creativity. In Journal of Physics: Conference Series, Vol. 1460, No.1, p. 012117). 2020.
[8] H. Harjono, W. Jufri and K. Arizona, Implementasi Media Tiga Dimensi Kemagnetan Berbasis Inkuiri Melalui Strategi Kooperatif Terhadap Sikap Ilmiah Siswa. Jurnal Pendidikan Fisika dan Teknologi, vol. 1, no. 1, pp. 15-23, 2015.

[9] I. Muslim, A. Halim and R. Safitri, Penerapan model pembelajaran PBL untuk meningkatkan penguasaan konsep dan keterampilan berpikir kritis siswa pada konsep elastisitas dan hokum Hooke di SMA Negeri Unggul Harapan Persada, Jurnal Pendidikan Sains Indonesia, vol.3, no.2, pp. 3550, 2015.

[10] L. Aprilianti, S. Irawati, and Kasrina, Peningkatan sikapi lmiah dan hasil belajar siswa dengan model problem based learning, Diklabio: Jurnal Pendidikan dan Pembelajaran Biologi, vol. 2, no. 1, pp, 58-67, 2018.

[11] N. Pohan, Pelaksanaan proses belajar melalui bimbingan aspek afektif, kognitif dan psikomotorik siswa di Madrasah Ibtidaiyah Swasta Amal Shaleh Medan (Doctoral dissertation, Universitas Islam Negeri Sumatera Utara), 2017.

[12] S. Sukaesih, Analisis sikap ilmiah dan tanggapan mahasiswa terhadap penerapan model pembelajaran berbasis praktikum. Jurnal Penelitian Pendidikan, vol. 28, no. 1, pp. 77-85. 2011.

[13] E.F. Wardani, Analisis Kemampuan Literasi Sains, Sikap Ilmiah Dan Merancang Mini Riset Mahasiswa Pgsd Stkip Muhammadiyah Bangka Belitung Pada Mata Kuliah Praktikum Ipa, Primary Education Journal Silampari, vol. 1, no, 1, pp. 13-23, 2019.

[14] N. Muhamad, Model Pembelajaran Berbasis Masalah untuk Meningkatkan Kemampuan BerpikirKritis dan Ketelitian Mahasiswa. Jurnal Pendidikan Universitas Garut, vol. 11, no. 2, pp. 153-163.2017.

[15] L. Aprilianti, S. Irawati, and Kasrina, Peningkatan sikapi lmiah dan hasil belajar siswa dengan model problem based learnin, Diklabio: Jurnal Pendidikan dan Pembelajaran Biologi, vol. 2, no 1, pp. 58-67. 2018.

[16] T.A.D. Handayani, W. Karyasa and N. Suardana, Komparasi peningkatan pemahaman konsep dan sikap ilmiah siswa SMA yang dibelajarkan dengan model pembelajaran problem based learning dan project based learning, e-Journal Program Pascasarjana Universitas Pendidikan Ganesha Program Studi Pendidikan IPA, vol. 5, pp.1-12, 2015.

[17] S. Mulyani, A. Gani, M. Syukri, T. Tarmizi, E. Elisa, N. Nurhasanah, and F. Fajriani, Penerapan Model Problem Based Learning pada Materi Alat-Alat Optik untuk Meningkatkan Kepercayaan Diri dan Kemampuan Menyelesaikan Masalah Kontekstual, Jurnal Pendidikan Sains Indonesia (Indonesian Journal of Science Education), vol.8, no.1, pp. 105-113, 2020.

[18] A. Yoesoef, Penerapan model problem based learning untuk meningkatkan kemampuan menanya dan penguasaan konsep Fisika kelas X MA 1 SMA Negeri 2 Kediri,Jurnal PINUS, vol. 1, no. 2, pp. 96-103, 2015 